\title{
Interpretation of Sura Ali Imrān verse 64 about Kalimatun Sawâ': an Analysis Study of Ma'na-cum- Maghza
}

\author{
$1^{\text {st }}$ Qurrata A'yun ${ }^{1}, 2^{\text {nd }}$ Lukita Fahriana $^{2}, 3^{\text {rd }}$ Kusmana $^{3}, 4^{\text {th }}$ Eva Nugraha $^{4}$, \\ $5^{\text {th }}$ Lilik Ummi Kultsum ${ }^{5}$ \\ \{qurrataayun55@gmail.com¹, lukitafahriana01@ gmail.com², kusmana@uinjkt.ac.id ${ }^{3}$, \\ eva.nugraha@uinjkt.ac.id ${ }^{4}$, lilik.ummi@uinjkt.ac.id ${ }^{5}$ \}
}

Sunan Kalijaga State Islamic University of Yogy akarta, Indonesia ${ }^{1}$, Postgraduate Sy arif Hiday atullah State Islamic University of Jakarta, Indonesia ${ }^{2,3,4,5}$

\begin{abstract}
This article aims to examine the interpretation of QS. Ali Imran [3]: 64 regarding Kalimatun Sawa' as a meeting point in the concept of plurality. This study used a descriptive qualitative approach with the ma'na-cum-maghza hermeneutic theory. The results of this study indicate that the Prophet's invitation against Christians and Jews to Islam is carried out through conversation and not with the element of coercion or threat. The conversation in it is to get to know each other and find common ground that is a common point between them. Thus, the plurality can be accepted as a blessing from Allah SWT. who are absent from the disputes and hostilities within them.
\end{abstract}

Keywords: Kalimatun sawa', ma'na cum maghza, plurality.

\section{Introduction}

Plurality is an undeniable reality. ${ }^{1}$ The essence of plurality is a potential that can be a blessing but can also be anathema to the universe, depending on how humans manage it. A well-managed plurality can be a blessing because plurality fosters curiosity, mobility, appreciation, mutual understanding, co-existence, and collaboration. However, a plurality that is not managed properly can be damning because it can lead to various prejudices. The prejudice that is not based on appreciation is suspicion. A plurality filled with suspicion only produces envy and jealousy. Envy and excessive jealousy can develop into hostility and produce conflict, division, and destruction.

Plurality management well can be realized in various ways. One of them is in the form of discourse to discuss, gather and share views, thoughts, and aspirations to eliminate existing forms of prejudice. History states that these discussion events have occurred between religious

\footnotetext{
${ }^{1}$ al-Qur'an also states that in essence, Allah wants diversity rather than uniformity (Surah Al-Mấidah [5]: 48.), all of that is created so that people know each other (QS Al-Hujurât [59]: 13) and competing in goodness (QS Al-Baqarah [2]: 148)
} 
communities, such as World Conference on Religion and Peace ${ }^{2}$ dan A Common Word Between Us and You "Kalimat Sawa' bainana wa bainakum (QS. Ali 'Imran 3: 64)". 3

Dialogue between religions through an open letter entitled "A Common Word Between Us and You" Kalimatun Sawa' bainana wa bainakum (Ali' Imran 3: 64) "then received a lot of attention from intellectuals in various religious institutions and world university institutions. Studies on this dialogue have been carried out by Miroslav Volf, Ghazi bin Muhammad and Melissa Yarrington,[3] Waleed El-Ansary and David K. Linnan,[4] Joseph Victor Edwin,[5] Joseph Lumbard,[6] Saifurrahman,[7] dan Sulanam.[8] Also, the understanding of the concept of the kalimatun sawa' (a common word) is discussed further through the views of Muslim intellectual figures, including in a study conducted by Mujianto Solichin,[9] Ummi Ati Uwaida,[10] Bahrur Rosi,[11] Abdul Khalid Aris,[12] Qurrata A'yun and Hasani Ahmad Said.[13] The studies above have not studied the interpretation of the main verse of the Sawa 'sentence, namely QS. Ali 'Imran 3: 64, especially by using the hermeneutic approach of the Koran. To be able to find out more about this, this paper is here and tries to reveal its interpretation with one of the hermeneutic approaches of the Koran ma'na cum maghza which was initiated by Sahiron Syamsuddin with three application steps; examines the analysis of language, the socio-historical context, and its significance. ${ }^{4}$

\footnotetext{
${ }^{2}$ This conference was held for the first time in Tokyo in 1970 and was attended by various religious figures. The conference continued in 1974 and 1979, in which it was formulated that peace is a world community built on the basis of love, freedom, justice and truth. For further information, see Foreword by Muhadjir Darwin in [1]

3 "A Common Word" "A Common Word" is an interfaith dialogue in the form of an international seminar. "A Common Word" appeared in response to Pope Benedict XVI's statement in the "Grand Oration" on September 12, 2006. The oration aroused the anger of Muslims because his statement was considered insulting the Prophet Muhammad and Islam. On October 13, 2006, 38 Muslim religious leaders and intellectuals sent an open letter to Pope Benedict to clarify his statement. Until finally the following year on October 13, 2007, the letter was followed up by the publication of an open letter signed by 138 religious leaders and Muslim intellectuals from around the world and addressed to 28 Christian religious leaders around the world. The letter is an invitation to all Christians to live in peace and harmony in the differences between "Muslims and Christians" in the framework of fostering and realizing world peace together. For more, see Introduction in [2]

${ }^{4}$ Sahiron Syamsuddin, born June 5, 1968, is an expert in contemporary Qur'an and interpretation from UIN Sunan Kalijaga Yogyakarta, currently serving as chairman of the Indonesian Association of Qur'anic and Interpretive Sciences (AIAT), Deputy Rector II of UIN Sunan Kalijaga, 2015 was the Steering Committee at the Netherlands-Indonesian Consortium. Among his works are Hermeneutika dan Pengembangan Ulumul Qur"an (cet.1: 2009, cet. 2: 2017), An examination of Bint al-Shati"s method of interpreting the Qur'an. (2000), Upaya integrasi hermeneutika dalam kajian al-Qur'an dan hadis: teori dan aplikasi (2011), Metode Intratekstualitas Muhammad Syahrur dalam Penafsiran Al-Qur"an (2002), Muhkkam and Mutashābih: An Analytical Study of al-Țabarī's and al-Zamakhsharī's Interpretations of Q.3:7 (1999), Integrasi Hermeneutika Hans Georg Gadamer ke dalam Ilmu Tafsir? Sebuah Proyek Pengembangan Metode Pembacaan Alquran pada Masa Kontemporer (2006), Hermeneutika al-Qur"an dan Hadis (2010), Studi Al-Qur"an Kontemporer: Wacana Baru Berbagai Metodologi Tafsir (2002), dan lainnya. [14]
} 


\section{Hermeneutics Ma'na cum Maghza: Methodology and Application Steps}

Ma'na-cum-magza hermeneutics is a theory of the interpretation of the Koran that was initiated by Sahiron Syamsuddin. Of course, this idea is inseparable from basic assumptions that stem from an attitude of wanting to "mediate" the pros and cons of using hermeneutics as a method of interpreting the Koran. Sahiron departs from the assumption that some hermeneutic ideas can be applied to the Ulümul Qur'an, and can even strengthen the method of interpreting the Koran. Substantially, hermeneutics and the science of exegesis are not different: they both teach how to understand and interpret a text correctly and accurately. What distinguishes the two is the history of their appearance, their scope, and the object of their discussion. Also, he argues that it is necessary to synthesize and integrate Islamic studies with "secular" or Western disciplines, as has been practiced by Islamic figures since the 3rd century AH.[15, hlm. 7-8]

Sahiron classified the typology of interpretation among Muslims today, into three schools, namely: (1) Quasi-objectivist traditionalists; according to this school, the teachings of the Qur'an must be understood, interpreted, and applied according to the understanding, interpretation, and application of the context in which the Qur'an was revealed to the Prophet Muhammad. and taught to sahabat.[15, hlm. 54] (2) Quasi-subjectivist; This school holds the view that interpretation is entirely the subjectivity of the interpreter because interpretive truth is relative. One of the figures of this school, Hassan Hanafi emphasized that every interpretation of the Koran must be greatly influenced by the interests and interests of the interpreter, therefore the interpretation of the Qur'an is pluralistic,[15, hlm. 56] not just one. (3) Progressive quasi-objectivist; this flow is the same as the first school in terms of exploring the original meaning, but the difference is that this flow makes the original meaning only as a starting point to find the message contained behind the literal text. Among the figures of this genre is Fazlul Rahman with the concept of double movement, Muhammad al-Thalibi with altafsir al-maqașidī and Nasr Hamid Abu Zayd with the concept of al-tafsir al-siyaqī.[15, hlm. 57-58]

Of the three schools of interpretation above, the traditionalist quasi-objectivist school is considered to impose universal Qur'anic principles in any context into the Qur'anic text, so that the understanding that is born tends to be textual or literal.[16, hlm. 55] Such an interpretation seems a bit stiff and unable to answer current problems, even has the potential to give birth to radicalism and so on. Meanwhile, the second genre, namely the quasi-subjectivist school tends to interpret the Qur'an at will and is very thick with the ideologies of its interpreters. The progressive quasi-objectivist school is more acceptable as an effort to develop the method of reciting the Koran at present. In interpreting the Qur'an, this school is not only fixated on the meaning from which the text was revealed, but seeks to capture the main message contained behind the original meaning of the text. In other words, this view can be referred to as "balanced hermeneutics",[15, hlm. 140] namely paying equal attention to the original meaning (al-ma'na al-așli) and the main message (significant; al-magza).

In essence, the ma'na-cum-magza theory is not new in the discourse of hermeneutics (the method of interpretation). As mentioned above, the ma'na-cum-magza theory is applied by paying equal attention to the meaning of the literal origin (al-ma'na al-așli) and the main message (significance; al-magza) behind the literal meaning. The ma'na-cum-magza theory is an effort to develop an interpretation method initiated by one of Gadamer's hermeneutic theories, namely the application theory (anwendung). As quoted by Sahiron, Gadamer stated 
that after an interpreter finds the intended meaning of a text when the text appears, he then develops the interpretation or re-actualization / reinterpretation while still paying attention to the continuity of this "new meaning" with the original meaning of the text.[15, hlm. 87] When the literal meaning of the text has been found, then the meaning is correlated with the possibility of a second and third meaning while still paying attention to the components contained in the literal meaning.[17, hlm. 102]

The same concept was put forward by Hirch using the terms meaning (meaning / meaning) and significance (significance). It distinguishes between meaning and significance. According to him, this distinction should not be limited to the basic standards surrounding the author's original intentions. However, this distinction should also take into account all matters related to anachronistic meanings and he realizes that the disclosure of meaning needs to take into account the broad context, and is not limited to the author's context.[18, hlm. 133-134] Also, among Muslim scholars, several figures have the same concept as ma'na-cum-magza theory, including al-Ghazali with the concept of al-ma'na al-zāhir (outward meaning) and al-ma'na al-batīn (inner meaning). Fazlul Rahman with his theory, double movement, and Nasr Hamid Abu Zayd with his ma'na and magza concepts. [15, hlm. 88]

All of the above interpretation theories idealize that in interpreting (the text) it is necessary to pay attention to the textual context through language analysis as the starting point, and the historical context of the text emerges through historical analys is, then digs for its main message (significance) to be contextualized according to the spirit of the times, places, and the time the text was interpreted.

However, according to Sahiron, all the hermeneutic theories above do not talk clearly about "significance" (magza). Therefore, in his ma'na-cum-magza theory, he adds an explanation of "significance". According to him, there are two kinds of significance: first, phenomenal significance, namely the main message that is understood and applied contextually and dynamically from the time of the prophet to the time the verse is interpreted in a certain period. Then this phenomenal significance is also divided into two types, namely: (a) historical phenomenal significance, namely the meaning of a verse or a collection of verses that was understood and applied at the time of revelation; (b) dynamic phenomenal significance, namely the message of the Qur'an which is understood and defined at the time a certain verse or collection of verses is interpreted, and after that, it is applied in life. Second, ideal significance, namely the ideal accumulation of understandings of the significance of the verse. This accumulated understanding will be known at the end/goal of human civilization desired by Allah SWT.[15, hlm. 140-141]

As previously explained, the main objective of an interpreter/reader when understanding a text, both the Qur'anic verse and the Prophet's hadith, is to explore the main message (significance) that is contained behind the literal meaning. However, before getting to the stage of extracting significance, several methodical steps need to be taken. The first step is language analysis; An interpreter must pay attention that the language used in the text-the Koran, for example, is Arabic in the 7th century AD. This is very important to do considering that language is dynamic. Therefore, the interpreter must be able to master the basics of linguistics such as synchronic-diachronic, syntagmatic-paradigmatic, and so on. Also, to sharpen this analysis the interpreter can perform intratextuality, namely comparing the use of a word being interpreted with its use in other hadiths. If necessary and possible, the interpreter also performs intertextual analysis, namely analysis by connecting and comparing the hadiths with other texts around the Qur'an, such as hadiths, Arabic poetry, and so on.[15, hlm. 141142] To assist in analyzing language, as well as its relation to the context of the emergence of 
the hadith text, the interpreter should first collect all the hadiths with one topic, as well as present the interpretation or syarh hadith by previous scholars.

After finding the original meaning (al-ma'na al-așli) of the verse text, the interpreter then explores the main message (magzā; significance) of the verse. Starting from historical phenomenal significance, namely by understanding the macro and micro socio-religious context of the people who lived at the time of the birth of a verse. Macro context is a context that includes the situation and conditions in Arabia at the time of the Prophet himself. The micro context is the small (specific) incidents behind the appearance of the verse which is commonly referred to as asbābun nuzul. And, dynamic phenomenal significance, namely by understanding the development of thought and "spirit-mass" during the interpretation of the Koran. Furthermore, the significance of the ideal,[15, hlm. 141-143] so that the interpreter can contextualize the magzā verse according to the present context.

\section{Analysis of the Interpretation of Ma'na cum Maghza in Sura Ali Imran [3] verse 64}

The equivalent of the sentence sawâ' in the Koran is found in one verse, namely in Sura Âli 'Imrân [3] verse 64:

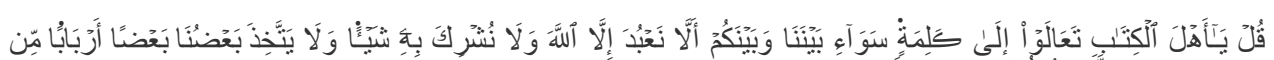

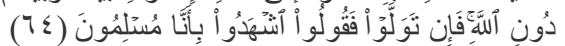

Say: "O People of the Book, let (hold) a sentence (provision) where there is no dispute between us and you, that we do not worship except Allah and we do not associate Him with anything and (also) some of us make some of the others. as a god other than Allah ". If they turn away then say to them: "Behold, that we are a people who surrender (to Allah)".

\subsection{Language Analysis}

The kalimatun sawa ${ }^{\prime}$ is a combination of two words, namely the word kalimah and sawa ${ }^{\text {: }}$ The word kalimah is the singular form of the word kalim, derived from the word kalama which means al-laf̧̣ah, mâ yanțiqu bihi al-insân mufradan kâna au murakkaban (words, what humans talk about, both one word (singular) and composed).[19, hlm. 695] Ibn Fâris mentions that kalama contains two original meanings, the first refers to intelligible speech (natqin mufhimin) and the second to injury (jarâhin). The form of the word kalimah comes into the first sense which means al-lafzah al-wâhidah al-mufhimah (a word that can be understood).[20, hlm. 131] Likewise al-Fairûz Âbadî in Qâmus al-Muhît explains that the word al-kalimah means al-lafżah and al-qasîdah (words and intentions).[21, hlm. 1155]

Kalimah (كَلِمَن) means a lafaz (word) which shows a single meaning, either consisting of one letter or more. Also means 'a phrase or expression which is perfectly meaningful'. For example Lâ ilâha illâ Allâh: kalimah al-tauhîid. Allah's sentence is His law or iradat.[22, hlm. 424] The word kalimah has also become an absorption word in the Big Indonesian Dictionary which means word or utterance.[23] The word kalimah (singular) in the Koran is mentioned 28 times, while in the plural form, whether it is leaned or not, it is mentioned 14 times. Apart from the word kalimah, other derivatives of the word kalama in the Koran are the word kalim (called four times), takliman (called once), kalâm (whether leaned or not, called four times, in 
the form of $f^{\prime} l$ mâdî called six kali, in the form of fi'l mudâri 'it is called 18 times ).[24, hlm. 722-723] The word al-kalimah in the Koran has many forms and meanings. As explained by al-Ashfahani in his book, there are at least more than three meanings. In Sura Al-Baqarah [2]: 124, what is meant by the word kalimâtin in the verse is something that Allah tested Ibrâhim in the form of an order to slaughter his son and circumcise him and a test other than the two. And the word kalimah to Prophet Zakariya which is contained in Sura Âli 'Imrân [3]: 39, means the kalimah al-tauhid.[25, hlm. 365] Sura Al-An'âm [6]: 115, has the intention of alqadiyyah, namely decision. Every decision is called kalimah whether the decision is a word or an action. Some say that what is meant by kalimatu rabbuka are His laws that have been determined and explained to His servants which have been conveyed, as in QS. Al-A'râf [7]: 137, QS. Thâhâ [20]: 129, QS. Asy-Syûrâ [42]: 14 and QS. Yûnus [10]: 82.[25, hlm. 368]

The word sawâ comes from the word sawwâ (سََّّى), sawwâ - yusawwî -taswiyah, the root word consists of three letters, namely sin - wawu - yâ.[22, hlm. 887] According to Ibn Faris, the root of the word refers to the meaning of istiqâmah (strong / firm) and the meaning of $i$ 'tidal baina syai 'ain (balance or similarity between two things). From the first meaning is born the meaning of 'perfecting' because something which is already perfect means that it is firm and firm, likewise the 'middle' part of a house or something else is called sawâ 'because the middle part is the most solid part among the other parts. Then, from the meaning of the two words sawa' are also used in the meaning of 'the same', so is the term la siyyamâ (more so) which means 'not the same' because the thing in question has something special and is not the same as the others.[26, hlm. 112]

Al-Fairûz Âbadî in Qâmus al-Muhint $\underline{t}$ explains that the word sawâ 'means al-'adl wa al-wast (fair and middle).[21, hlm. 1297] Al-Ashfahani in his book discusses the word sawâ' in the part of the word sawâ. The word al-musâwâh means equality in size and scale. It is said in the

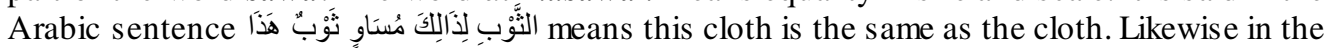

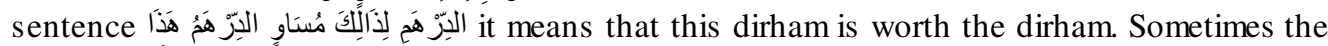

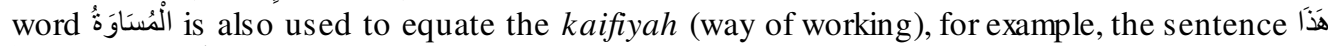

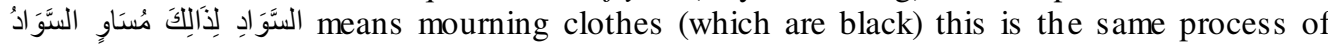
making it with that mourning dress. Although the essence of the equation returns to the location where it was made, not in the type of dress, the sentence is used to describe the similarity.[27, hlm. 328]

The derivation of the word sawâ in the Koran according to al-Ashfahani has a different meaning. One of them, the word اسنتَََى which means the same thing, can be used in two types; one of them is if there are two or more fâ'il (subjects), for example like the sentence means Zaid and 'Amru are the same, in this case, they mean the same thing. As in the word of Allah QS. At-Taubah [9]: 19. While the type of use of the word represent a type, for example like the word of Allah in QS. An-Najm [53]: 6 and QS. A1-

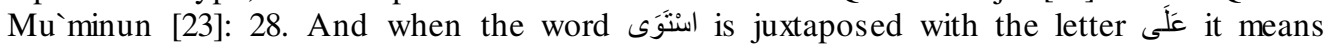
mastery, for example as Allah says. Thâhâ [20]: 5. Some say that the meaning of this verse is all the same before Him between those in heaven and on earth, it means that everything is upright with the will of Allah to equalize everything, this is like the word of Allah QS. AlBaqarah [2]: 29. Some say that the verse means that everything is the same before Him, so there is nothing closer to Him than the others because Allah SWT. not like a body (physical) that is in one place without another place. When the word استُنَّ is juxtaposed with the letter إِلَى , then it means the final achievement, either in the physical sense, or in the sense of mastery or management, and regarding this, it is contained in the word of Allah in QS. Fushshilat [41]: 11. then nothing is closer to Him than anything else, because Allah SWT. not like a body (physical) that is in one place without another place. When the word اسْنَوَى is juxtaposed with 
the letter إِلَى, then it means the final achievement, either in the physical sense, or in the sense of mastery or management, and regarding this, it is contained in the word of Allah in QS. Fushshilat [41]: 11. then there is nothing closer to Him than anything else, because of Allah SWT. not like a body (physical) that is in one place without another place. When the word إِلَّى in juxtaposed with the letter it means the final achievement, either in the physical sense, or in the sense of mastery or management, and regarding this, it is contained in the word of Allah in QS. Fushshilat [41]: 11.[27, hlm. 329-330]

The word السَّوِيُّ is used for people who are free from the attitude of ifrât (exaggeration in something) and tafrit (reducing the rights of something) both in terms of size and manner. As in His word QS. Maryam [19]: 10 and QS. Thâhâ [20]: 135. The sentence meَوِيُّ كَكَانْ middle place, he can use the word سُوَيٌ - سَوِيٌ - سَوَاءٌ means the same, that is, the sides are equal. And the sentence can be used in the form of nature and time, as long as the word is mashdar. As in QS. Ash-Shâffât [37]: 55, QS. Al-Baqarah [2]: 108, and QS. Al-Anfâl [8]: 58. Whereas in QS. Âli 'Imrân [3]: 64 the meaning of the word is fair or righteous in law. And in QS. Al-Baqarah [2]: 6, QS. Al-Munâfiqûn [63]: 6, QS. Ibrahim [14]: 21, and QS. Al-Hajj [22]: 25 means the same. The word سَوَ اءوَ other than. The sentence سِوَ الََ رَجُلْ عِنْدِي means I have someone other than you, which means someone else is filling your place besides yourself or replacing you.[27, hlm. 334-335]

The combination of the words kalimah and sawâ 'into the sentence sawâ' in a linguistic principle is something special because the word sawa ${ }^{\prime}$ does not follow the form of the word kalimah (muannats). This is explained by al-Tabarî who quotes linguists, that the word sawâ' in this verse is an isim and not a characteristic of the word kalimah so that its form follows that word.[28, hlm. 445]

The meaning of the kalimatun sawa' in language has also been discussed by al-Tabarî,[28, hlm. 441] al-Qurtubî,[29, hlm. 288] dan al-Marâghî[30, hlm. 308-309] in the interpretation agreed to interpret the kalimatun sawa' as the same and fair sentence or words between us and you there is no difference. These sayings were agreed upon by the Apostles and in the Books that Allah revealed to them. What is meant by a fair agreement or speech is only to worship or not to submit except to Allah Almighty and not associate him with anything. Thus, Islam and Ahl al-kitâb both believe that the universe is the creation of one God, namely Allah who has sent the prophets and messengers.

\subsection{Socio-Historical Context of Sura Ali 'Imran [3] verse 64}

This verse is included in the category of madaniyah verses, namely those that came down after the migration of the Prophet Muhammad and his companions from Mecca to Medina. Once the Prophet reached Medina in 622 AD, he discovered that the Madina people were a plural society both in religious and ethnic terms. Apart from Muslims from the Ansar and Muhajirin groups, there also lived Jews, Christians, and idolaters, even long before the Prophet's migration. About the Arab tribes in the city, at least, there are two main tribes, namely Aus and Khazraj, which are at odds with each other. Considering the need for unity between the religious and tribal communities there, the Prophet Muhammad then initiated the "Medina Charter" (Mithaq al-Madina). With this charter, all components of the city can live together in harmony and help each other build civilization.[31, hlm. 133] In full, the contents of the Medina agreement are contained in Ibn Ishaq's Sirah Muhammad, which has been quoted by many historical figures.[32, hlm. 231-233], [33, hlm. 84] Among the contents of the Medina Charter is that the state recognizes and protects the freedom to practice their 
respective religions, all people have the same position as members of society.[33, hlm. 93-94] So that at that time, the people of Medina could live side by side in peace and harmony.

The beginning of Surat Ali 'Imran from the first verse to the eighty-three verse came down to a messenger from the people of Najran who came on $9 \mathrm{H}$. Narrated by al-Baihaqi in Dalail an-Nubuwah, Ibn Ishaq said, telling me Muhammad bin Sahal bin Abi Umamah by saying, "When the people of Najran came to the Messenger of Allah. Asking about Isa bin Maryam, down on them the beginning of the verse of the letter Ali 'Imran to the verse eighties".[34, hlm. 91]

Verse 64 is motivated by the incident mubahalah ${ }^{5}$ which happened in verses $59-63 .^{6}$ The invitation to kalimatun sawâ (meeting point) is the final answer to the mubahalah story. Narrated by Ibn Ishaq in his sirah, the mubahalah event was preceded by the arrival of the Christian messenger Najran to the Prophet. The delegation consisted of 60 riders. Among them, 14 people have ahead. The 60 people left the matter to three people. The three people are Aqib, Sayyid, and Abu Harithah bin Alqamah. The three of them are leaders, smart people in negotiations. They went to Medina to meet the Messenger of Allah. And entered the mosque when he was praying Asr. When the time for their prayers comes, they also offer prayers in the mosque. Rasulullah saw. also said to let them worship. The three messengers also talked with the Messenger of Allah, they said about Jesus as Allah, son of Allah, and the third god along with their information about these three things. Until finally the Prophet said to the two priests, "Enter Islam, you!" both answered, "We have converted to Islam." The Prophet said, "Surely you have not converted to Islam. Then Islam! " Both of them replied, "We have even converted to Islam before you." The Prophet said, "You both lie. You reject Islam. You also think that Allah has children. Your worship of the cross. And you also eat pork. " The two priests asked, "Then who is the father, O Muhammad?" Then Rasulullah saw. Shut up and don't answer both of them. In this regard, Allah sent down verses starting from the beginning of Surah Ali Imran up to 80 verses.[36, hlm. 525-526]

After Rasulullah saw. receiving information and explanations from Allah as a basis for resolving disputes between him and them, he was ordered to invite them to change, if they continued to reject the decision. The Prophet invited them to curse each other. But they asked for an opportunity to ponder the matter, and returned to express their opinion about the change of Prophet's invitation. This is none other than because they know that Muhammad was a prophet who was sent, and no one has ever cursed a prophet. If anyone dared to curse him, then he would indeed perish to the roots. Aqib the leader also suggested returning to embracing the opinion held by Christians about Jesus and leaving Muhammad, and returning to their country. After negotiating, they returned to the Prophet. while saying, 'O Abu Qasim, we have decided not to curse you, let you follow your religion, and we will return to our religion. However, please send one of your friends whom you are pleased with to be with us and who will decide disputes between us regarding various issues related to our wealth. We are willing to be punished by him.' After performing dhur prayer, the Prophet finally decided to send Abu Ubaidah bin al-Jarah to go with the Najran Christians and decide the case which they disputed with rights.[41, hlm. 381]

Apart from the background of the debate with Najran's envoy to the incident of mubahalah, this verse is also the content of the letter sent by the Prophet to King Heraclius in Rome. This

\footnotetext{
${ }^{5}$ Mubahalah is each party among people with different opinions praying to God earnestly, that Allah will condemn the party who is lying. The Prophet invited the Christian emissary Najran to pray but they did not dare and this is proof of the truth of the Prophet Muhammad. See footnote about mubahalah on [35] ${ }^{6}$ This is expressed in many interpretations, including deep [29], [36]-[40]
} 
explanation has been widely quoted by commentators, ${ }^{7}$ one of his narrations is in sharah Bukhari on his narration which he presented through the Az-Zuhri route, from Ubaidillah ibn Abdullah ibn Atabah ibn Mas'ud, from Ibn Abbas, from Abu Sufyan about his story when he came to the emperor, then the emperor asked him about the text of the Prophet. Saw., His qualities and actions, and what he cried out for. Then Abu Sufyan told the whole thing clearly and plainly. Even though at that time Abu Sufyan was still polytheist and had not converted to Islam, this happened after the Hudaibiyyah Agreement and before the conquest of the city of Mecca, as explained by the hadith in question. Also when asked what was the Prophet. ever committed treason? So Abu Sufyan replied, "No. And we parted with him for a time, during that time we didn't know what he was doing. "Then Abu Sufyan said," I cannot add any news other than that. "The main purpose of this mediation is that the letter of the Prophet Muhammad was delivered to the emperor which reads as follows : [36, hlm. 529]

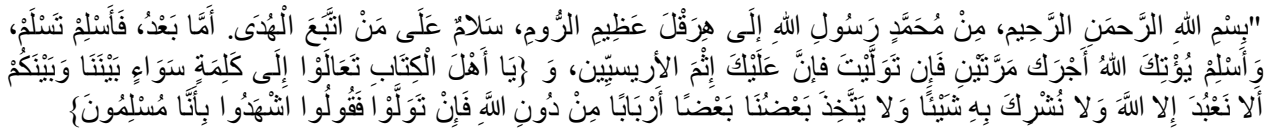

In the name of Allah, the Most Gracious and the Most Merciful, from Muhammad Rasulullah, addressed to Heraclius, the ruler of the Roman Empire, may the greatest salvation be to those who follow the instructions. Amma Ba'du: Then enter Islam, you will be safe, and enter Islam, surely Allah will reward you twice. But if you turn away, then you are bearing the sins of the arisins (peasants). And in it is also mentioned His words: O People of the Book, let's come to a sentence (provision) where there is no dispute between us and you, that we do not worship except Allah and we do not associate Him with anything and (also) some of us make some others as gods apart from Allah. If they turn away, then say to them, "Witness that we are a people who surrender (to Allah)." (Ali Imran: 64)

Apart from being revealed to the Christian envoys of Najran and the kings of Rome, the commentators also explained that this verse was revealed to the Jews of Medina. This is because the khitab contained in this verse is the man of the book. In explaining this, alQurthubi and al-Tabari explain two differences, first, this verse is intended for the expert of Najran by quoting the narrative of Muhammad bin Ja'far bin Zubair, and Ibn Zaid, and alSuddi, second, for the Jews of Medina by quoting the history of Qatadah and Ibn Juraij. Meanwhile, both (al-Qurthubi and al-Tabari) agreed to categorize the two groups, namely the Narani Najran and the Madina Jews into the khitab of the book in this verse, because they were both given books, namely the Bible and the Torah.[28, hlm. 442], [29, hlm. 289]

In another interpretation, Wahbah Zuhaili explained that ahl al-kitâb in this verse were those who have revealed to him the holy book, Torah, Zabur, the Bible, and the Koran.[44, hlm. 290-91] M. Quraish Shihab explains that ahl al-kitâb in this verse is not only the Najran Christian delegation as referred to in the previous verse but consists of all Jews and Christians. He also quoted the provisional opinion of scholars who included groups suspected of having holy books in their meaning, either residing in Medina or other areas. ${ }^{8}$ He also said that the

${ }^{7}$ Interpretations that discuss this da'wah letter can be found in Tafsir al-Baghawi, Tafsir al-Qurthubi, Tafsir Ibn Kathir traced in [38, hlm. 609], [39, hlm. 279], [42], [43, hlm. 81]

${ }^{8}$ In another book, M. Quraish Shihab explains the meaning of ahl al-kitâb and the opinions of other scholars on this matter. Like the opinion of Imam Shafi'i who stated that the so-called ahl al-kitâb are Jews and Christians of the descent of the Israelites, not including other nations who adhere to Judaism and Christianity. Imam Abu Hanifah and scholar Hanafiah stated that what is called ahl al-kitâb is any one who believes in one of the prophets, or a book that has been revealed by Allah Almighty, is not 
message of this verse was addressed to all of them (in the sense of ahl al-kitâb) even until the end of time.[40, hlm. 108]

\subsection{The Significance of Kalimatun Sawa' in Sura Ali Imran [3] verse 64}

Through the above reading, it can be understood that its phenomenal significance is the preaching of the Prophet Muhammad. against Christians and Jews to Islam through conversations between them and there is no compulsion in it. Although in the end, this debate did not make Christians and Jews converted to Islam, but basically, they have realized the truth of the prophetic message, so they also refuse to change and return to their country by guaranteeing their assets to Muslims. The kalimatun sawa' here is the same and fair sentence among the People of the Book, that the prophetic treatises namely faith and worship are only to Allah Almighty, have been written and taught in their previous books. So the invitation/da'wah of the Prophet to this meeting point is nothing new but has existed before as brought by the Prophets who were sent to their people.

The form of the Prophet's invitation to spread the teachings of Islam amidst the differences of these peoples is one of the ways that should be exemplified in the relationship between religions and mankind in general. Attempts to reach the common ground (kalimatun sawa') amid diversity is certainly a challenge, especially in today's society, where there is rapid development in every element. But it is not impossible to reach it, as was also exemplified by the Prophet, we can also try to reach the common ground. If we meet at one point, then we should cooperate in that. But if we don't meet at one point (belief in God for example), then let's try to reach another point, namely competing with each other for goodness.[46]

The main message (significance) in this verse is to try to find common ground (kalimatun sawa') among each other, this is based on the awareness of the understanding that Allah has determined the creation of humans with their diversity. One of these searches is the form of dialogue to get to know each other so that there is no disagreement, can work together for good, and build a better civilization for the future.

\section{Conclusion}

The word kalimatun sawa' in the al-Qur'an is contained in Surat Ali 'Imran verse 64. Kalimatun sawa' literally means the same sentence. Meanwhile, after analyzing the interpretation using the ma'na cum maghza approach, the significance is first, the invitation of the Prophet Muhammad. against Christians and Jews to Is lam through conversations between them and there is no compulsion in it. The invitation is given the term kalimatun sawa' because the invitation to believe and worship is only to Allah SWT. has also been contained in their previous books so that there is no difference between them in that matter. Second, inviting people to try to find common ground (kalimatun sawa') among each other. This is based on the awareness of the understanding that Allah has determined human creation with

limited to groups of followers of the Jewish and Christian religions. Thus, if there are people who only believe in Suhuf Ibrâhim or the Book of Zabur, then they are included in the term ahl al-kitâb. In addition, some salaf scholars state that every people who are thought to have a holy book can be considered as ahl al-kitâb, like the Magi. The conclusion drawn by Quraish Shihab is that what is meant by ahl al-kitâb is all adherents of Judaism and Christianity, anytime, anywhere and from whatever descent they are. See [45, hlm. 336-386] 
its diversity. One of these searches is obtained through the form of dialogue to get to know each other so that there is no dispute, can work together in goodness, and build a better civilization for the future. 


\section{References}

[1] Z. Maliki, Agama Rakyat Agama Penguasa: Konstruksi tentang Realitas Agama dan Demokrasi. Yogy akarta: Galang Press, 2000.

[2] Kalimatun Sawa A Common Word Between Us and You. Jordan: The Royal Aal Al-Bayt Institute for Islamic Thought, 2009.

[3] M. Volf, G. bin M. bin Talal, G. bin M. (Prince of Jordan.), dan M. Yarrington, A Common Word: Muslims and Christians on Loving God and Neighbor. Wm. B. Eerdmans Publishing, 2010.

[4] W. El-Ansary dan D. Linnan, Muslim and Christian Understanding: Theory and Application of "A Common Word." Springer, 2010.

[5] J. V. Edwin, "A Common Word Between Us and You: A New Departure in Muslim Attitudes Towards Christianity," University of Birmingham, 2010.

[6] J. E. B. Lumbard, The Uncommonality of a Common Word. Crown Center for Middle East Studies, Brandeis University, 2009.

[7] S. Saifurrahman, "Muslim and Christian Understanding: Theory and Aplication of 'a Common Word," TASÂMUH, vol. 13, no. 2, Art. no. 2, Jun 2016, Diakses: Sep 01, 2020. [Daring]. Tersedia pada: https://journal.uinmataram.ac.id/index.php/tasamuh/article/view/165.

[8] S. Sulanam, “A COMMON WORD': Sebagai Titik Kesepahaman Muslim - Kristen,” Toler. Media Ilm. Komun. Umat Beragama, vol. 11, no. 1, Art. no. 1, Nov 2019, doi: 10.24014/trs.v11i1.8287.

[9] M. Solichin, "Muslim and Christian Understanding: Theory and Application of 'A Common Word Between Us and You' (Studi Pemikiran Mohamed Talbi dalam Buku 'Iyal Allah Afkar Jadidah fi "Alaqat al-Muslim bi Nafsihi wa bi al-Akharin)," J. Religi J. Studi Islam, vol. 6, no. 1, 2016.

[10] U. A. Uwaida, "Konsep Kalimatun Sawa Menurut Nurcholish Majid," skripsi, UIN Sunan Kalijaga Yogyakarta, 2015.

[11] B. Rosi, “'Kalimah Sawa' Sebagai Konsep Teologi Inklusif Nurcholish Madjid,” Okt 2017, Diakses: Mei 27, 2020. [Daring]. Tersedia pada: http://repository .uinjkt.ac.id/dspace/handle/123456789/36520.

[12] A. K. Aris, "Penafsiran Nurcholish Madjid Atas Al-Qur'an (studi Analisis Surat Ali Imrān Ayat 64)," Agu 2020, Diakses: Okt 14, 2020. [Daring]. Tersedia pada: http://repository .uinjkt.ac.id/dspace/handle/123456789/52150.

[13] Q. A'yun, "Kalimatun Sawâ' in the Perspective of Indonesian's Interpretation," Afkaruna Indones. Interdiscip. J. Islam. Stud., vol. 15, no. 1, Art. no. 1, Jun 2019, doi: 10.18196/AIIJIS.2019.0095.55-81.

[14] www.uin-suka.ac.id, "UIN Sunan Kalijaga Yogyakarta." https://uinsuka.ac.id/id/page/detil_dosen/196806051994031003-Sahiron (diakses Mei 29, 2020).

[15] S. Syamsuddin, Hermeneutika dan Pengembangan Ulumul Qur'an. Yogyakarta: Nawasea Press, 2017.

[16] A. Mustaqim, Epistemologi Tafsir Kontemporer. Yogy akarta: LKis, 2010.

[17] M. Hanif, "Hermeneutika Hans-Georg Gadamer dan Signifikansiny a Terhadap Penafsiran AlQur'an," MAGHZA J. Ilmu Al-Quran Dan Tafsir, vol. 2, no. 1, hlm. 93-108, Mei 2017, doi: 10.24090/maghza.v2i1.1546.

[18] H. Prakosa, "Penyingkapan Makna: Sekedar Kembali ke Maksud Pengarang? (Pokok-pokok Pemikiran E.D. Hirsch Jr. Tentang Interpretasi," dalam Upaya Integrasi Hermeneutika Dalam Kajian Alquran dan Hadis (Teori dan Aplikasi), Yogyakarta: Lembaga Penelitian UIN Sunan Kalijaga, 2011.

[19] L. Ma'lûf, Al-Munjid fi al-Lughah. Bairût: Dar al-Masyriq, 2002.

[20] A.-husain A. ibn F. Ibn Zakariya, Mu'jam Maqâyis al-Lughah, vol. 5. Mesir: Maktabah alKhabakhî, 1981.

[21] M. bin Y. al-Fairûz Âbadî, Al-Qâmûs al-Muhît. Bairût: Al-Resalah, 2003.

[22] M. Q. Shihab, Ensiklopedi Al-Qur'an: Kajian Kosakata. Jakarta: Lentera Hati, 2007. 
[23] "Hasil Pencarian - KBBI Daring." https://kbbi.kemdikbud.go.id/entri/kalimah (diakses Jun 22, 2020).

[24] M. F. 'Abd al-Bâqî, al-Mu'jam al-Mufahras li Alfâz al-Qur'ân al-Karîm. Mesir: Dâr al-Hadîts, 1996.

[25] A.-R. Al-Ashfahani, Al-Mufradât fî Gharîb al-Qur'ân, vol. 3. Depok: Pustaka Khazanah Fawa`id, 2017.

[26] A.-husain A. ibn F. Ibn Zakariya, Mu’jam Maqâyis al-Lughah, vol. 3. Mesir: Maktabah alKhabakhî, 1981.

[27] A.-R. Al-Ashfahani, Al-Mufradât fî Gharîb al-Qur'ân, vol. 2. Depok: Pustaka Khazanah Fawa`id, 2017.

[28] Al-Tabarî, Jâmi' al-Bayân 'an Ta 'wîl Ayi al-Qur'ân, vol. 5. Jakarta: Pustaka Azzam, 2008.

[29] Al-Qurthubi, Al-Jâmi' li Ahkâm al-Qur'ân, vol. 4. Jakarta: Pustaka Azzam, 2008.

[30] M. al-Maraghi, Tafsir al-Maraghi. Semarang: CV Toha Putra, 1989.

[31] S. Syamsuddin, "Ma'na-Cum-M aghza Approach to the Qur'an: Interpretation of Q. 5:51," Nov 2017, hlm. 131-136, doi: 10.2991/icqhs-17.2018.21.

[32] A. Guillaume, The Life of Muhammad: A Translation of Ibn Ishaq's Sirat Rasul Allah. Karachi: Oxford University Press, 1970.

[33] N. Shiddiqi, Jeram-jeram Peradaban Muslim. Yogy akarta: Pustaka Pelajar, 1996.

[34] I. As-Suyuthi, Asbabun Nuzul: Sebab-sebab Turunnya Ayat Al-Qur'an. Pustaka Al-Kautsar, 2014.

[35] K. Agama RI, Al-Qur'an dan Terjemahnya. Bandung: PT. Sygma Examedia Arkanleema, 2010.

[36] M. N. Ar-Rifa'i, Kemudahan dari Allah: ringkasan tafsir Ibnu Katsir. Gema Insani, 1999.

[37] S. Quthb, Fi Zhilal al-Qur'an, vol. II. Jakarta: Robbani Press, 2001.

[38] M. H. ash-Shiddieqy, Tafsir al-Qur'anul Majid an-Nuur. Semarang: PT. Pustaka Rizki Putra, 2000.

[39] H. Hamka, Tafsir Al-Azhar Juz III. Jakarta: Pustaka Panjimas, 2003.

[40] M. Q. Shihab, Tafsir Al-Misbâh. Pesan, Kesan dan Keserasian Al-Qur'an. Jakarta: Lentera Hati, 2006.

[41] I. Ishaq, Sirah Nabawiyah; Sejarah Lengkap Kehidupan Rasulullah saw. Jakarta: Akbar Media, 2012.

[42] "Al Quran - KSU Electronic Moshaf project." http://quran.ksu.edu.sa/index.php ?l=en\#ay a=3_64\&m=hafs\&qaree=husary \&trans=en_sh （diakses Jun 22, 2020).

[43] I. Taimiyyah, Tafsîr Syaikh al-Islâm Ibn Taimiyyah, vol. II. Saudi Arabia: Dar Ibn al-Jauzi, 1432.

[44] W. Zuhaili, Tafsir al-Munir, vol. 2. Jakarta: Gema Insani, 2013.

[45] M. Q. Shihab, Wawasan al-Qur'an, Tafsir Maudhu'i atas Pelbagai Persoalan Umat. Bandung: Mizan, 1997.

[46] Keragaman Kehendak Tuhan: Inilah Perjanjian Nabi dengan Kaum Nasrani (Part 2)| Shihab \& Shihab. 